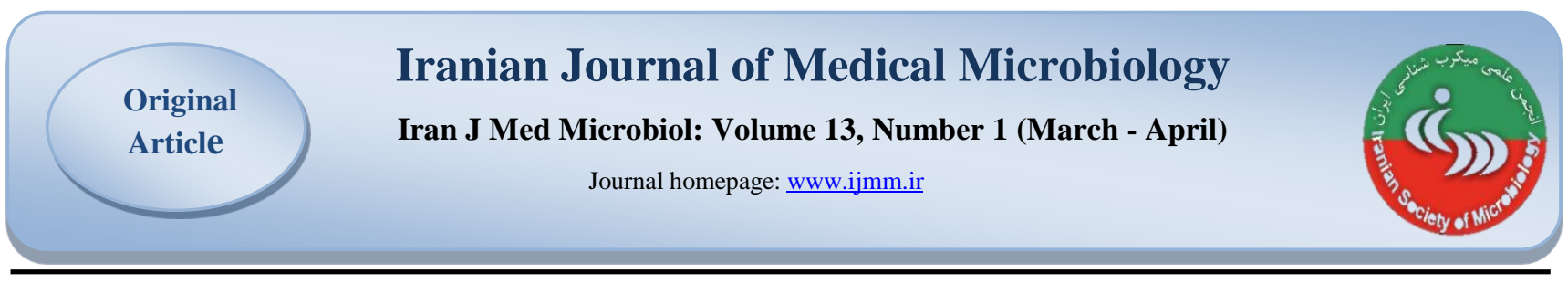

\title{
Determining Difference in Evolutionary Variation of Bacterial RecA Proteins vs 16SrRNA Genes Using 16S-Toxonomy Tree
}

\author{
Avisa Maleki ${ }^{1}$, Hossein Fahimi ${ }^{1}$, Mohammad Taghizadeh ${ }^{2}$ *
}

1. Department of Genetics, Faculty of Advanced Science and Technology, Tehran Medical Sciences, Islamic Azad University, Tehran, Iran

2. Department of Biotechnology, Faculty of Advanced Science and Technology, Tehran Medical Sciences, Islamic Azad University, Tehran, Iran

\section{Article Information}

\section{Article Subject: \\ Microbial Bioinformatics}

DOI: $10.30699 /$ ijmm.13.1.32

Corresponding author:

Mohammad Taghizadeh

Department of Biotechnology, Faculty of Advanced Science and Technology,

Tehran Medical Sciences, Islamic Azad

University, Tehran, Iran

\section{Email:}

mtaghizadeh@alumni.ut.ac.ir

Use your device to scan and read the article online

\section{Abstract}

Background and Aims: The rate of variation in various genes of a bacterial species is different during evolution. Therefore, in systematic bacterial studies many researchers compare the phylogenetic tree of a particular gene to the standard tree of an rRNA gene. Regarding the importance of $16 \operatorname{SrRNA}$ gene and the evolutionary process of RecA protein family, we investigated the changes in sequences of the RecA protein family in selected bacterial phylums in comparing with their 16SrRNA genes.

Materials and Methods: For this purpose, sequences of the RecA protein family were extracted from Uniprot database (with some help from ProSite) and then they were categorized by using CD-hit algorithm. One species was selected from each category. Then we found 16SrRNA complete sequences for same species. After that, based on the Average Alignment Score (AAS), the 16S-taxonomic tree was obtained. Furthermore, Similar calculations were considered for corresponding RecA proteins phylums.

Results: By comparing amount of AAS in 16SrRNA phylums and RecA phylums, we observed that the Actinobacteria phylum is the closest to the header phylum in the 16Staxonomy tree, but this phylum in the RecA is the most distant to the header phylum, on the other hand, the position of the cyanobacteria phylum remains the same in both calculations, which indicates the least amount of changes in the genus and species of this phylum.

Conclusion: The 16S-taxonomy tree which has been compiled and presented in this study for the first time is different from the available bioinformatics algorithms for phylogenetic tree drawing. Finding the species with the highest and lowest rates of changes, can be a type of prediction method for indicating the reasons why bacteria become resistant to drugs over a long period of time.

Keywords: Taxonomy tree, Bacterial RecA protein family, 16SrRNA gene, 16S-taxonomy tree, Drug resistance

Received: 2018/11/05 Accepted: 2019/05/15 Available online: 2019/06/20

Copyright ( 92019 Iranian Journal of Medical Microbiology. This is an open-access article distributed under the terms of the Creative Commons Attribution License (http://creativecommons.org/licenses/by/4.0), which permits unrestricted use, distribution, and reproduction in any medium, provided the original work is properly cited

How to cite this article:

Maleki A, Fahimi H, Taghizadeh M. Determining Difference in Evolutionary Variation of Bacterial RecA proteins vs 16SrRNA Genes by using 16s_Toxonomy Tree. Iran J Med Microbiol. 2019; 13 (1) :32-43 


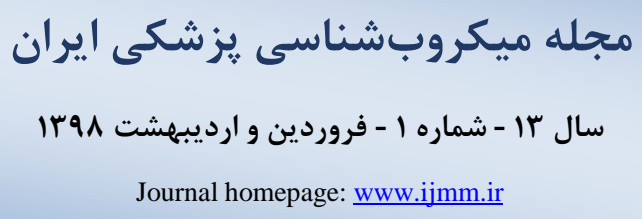

تعيين تفاوت تغييرات در طول تكامل براى بروتئينهاى باكتريايى RecA در مقايسه با ذن 16SrRNA با استفاده از

\author{
درخت 16S-تاكسونومى بروني

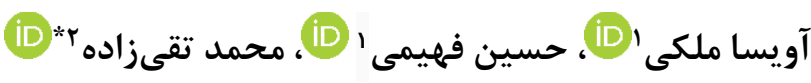

ا. . كروه زنتيك، دانشكدة علوم و فناورىهاى نوين، علوم يزشكى تهران، دانشكاه آزاد اسلامى، تهران، ايران

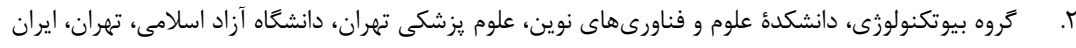

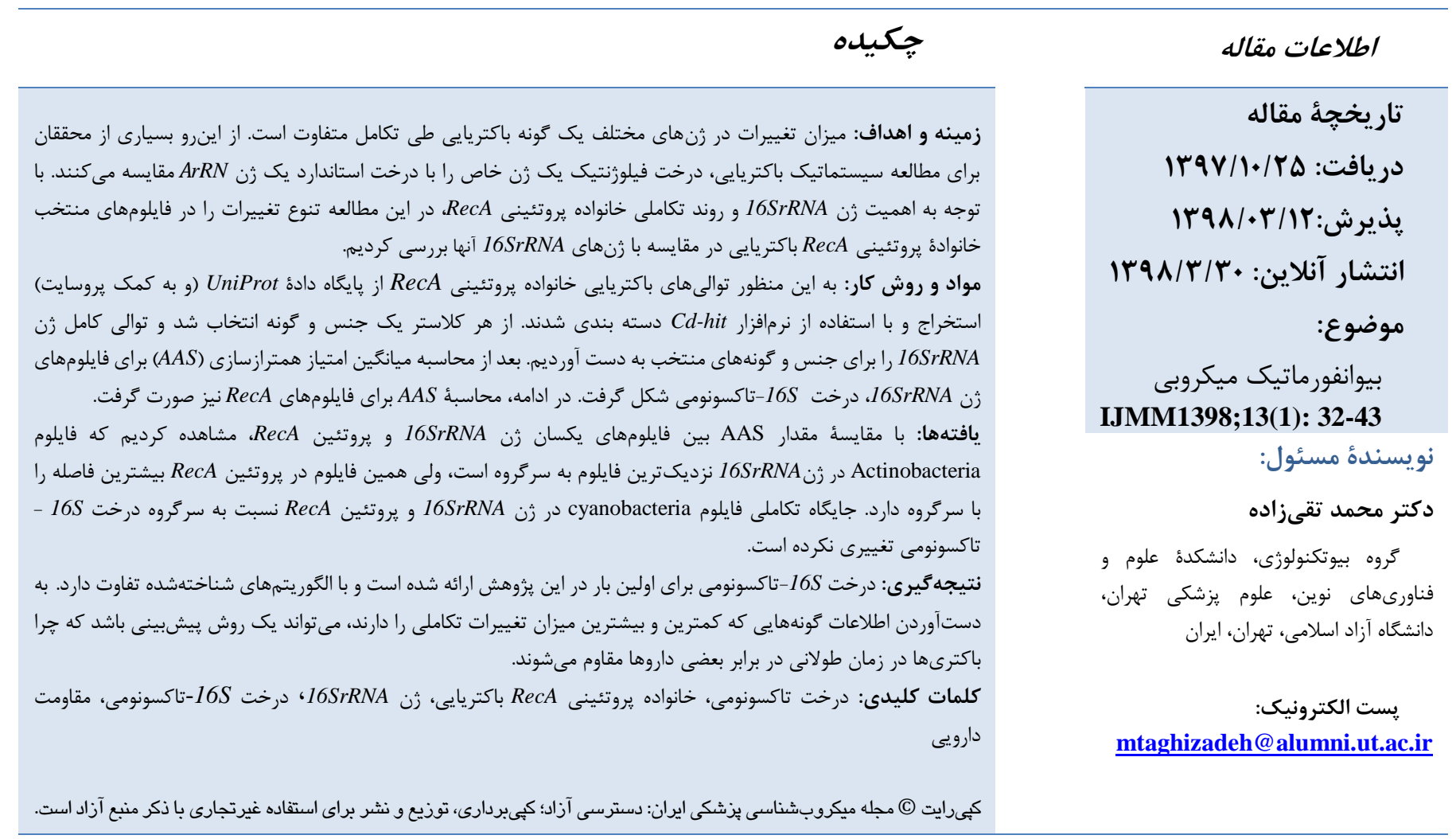

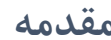

يروتئين RecA باكتريايى براى نوتركيبى همولوكَ و ترميم

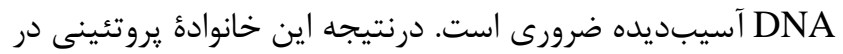

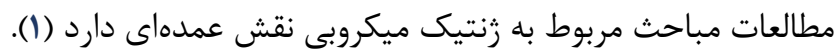

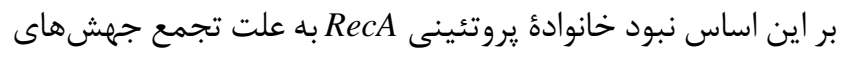

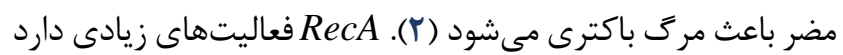

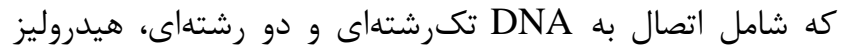

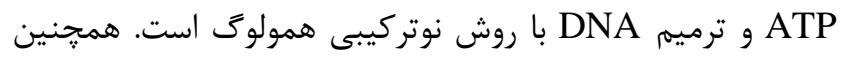

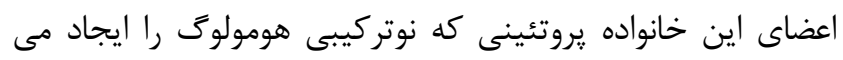

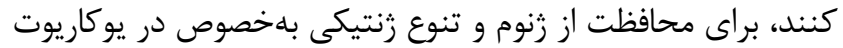

سرعت تغييرات زنهاى مختلف در طول تكامل با يكديكر

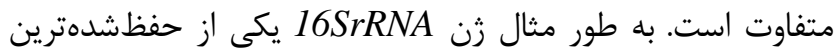

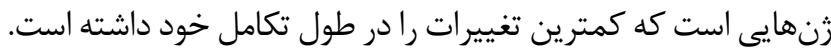

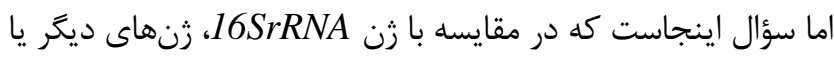

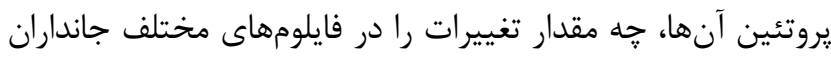

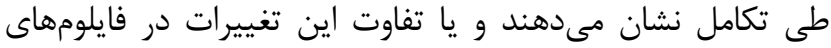

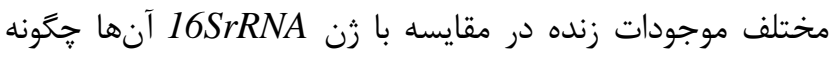

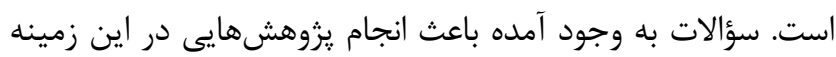
شده است كه در ادامهبه بررسى برخى از آنها خواهيه بردي برداخت. 
زنهاى rRNA براى زندهماندن همأ موجودات ضرورى

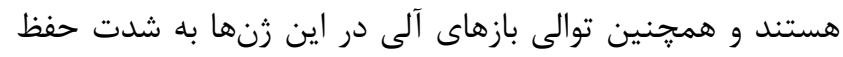

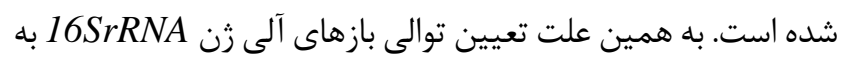

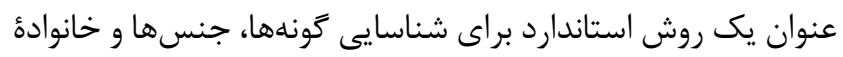

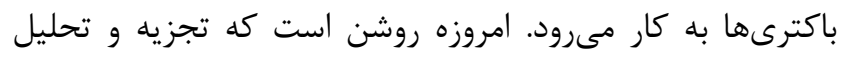

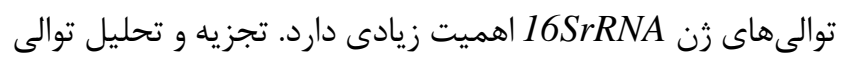

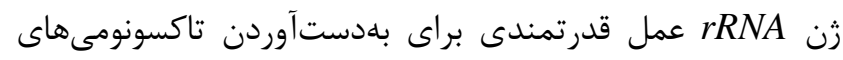

$$
\text { ميكروبى است (•l، (11). }
$$

در يزوهشى كه سال IV I ا انجام شد، براى شناسايى و طبقه

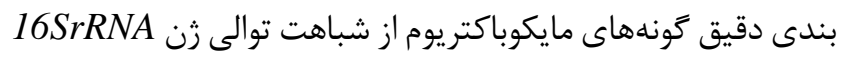

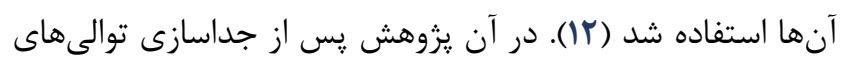

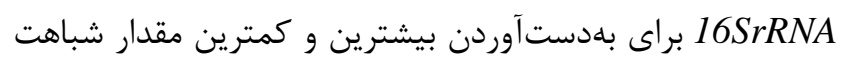

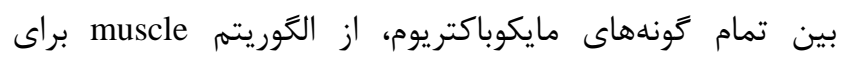

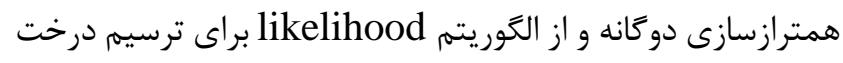

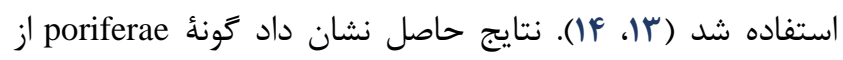

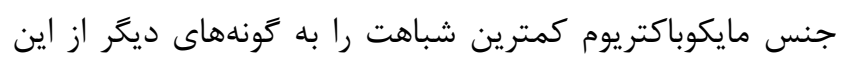

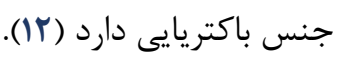

در يزوهشى ديخر به مقايسٔ درخت فيلوزنى زن 16SrRNA و و RecA

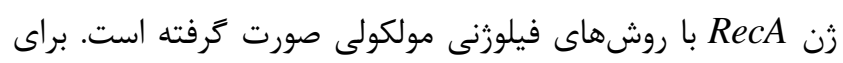

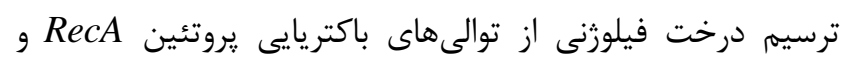

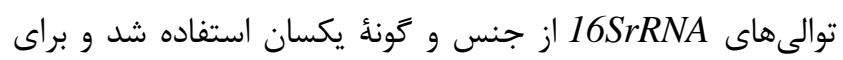

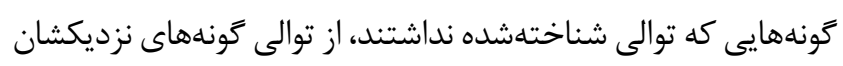

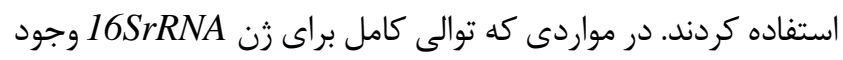

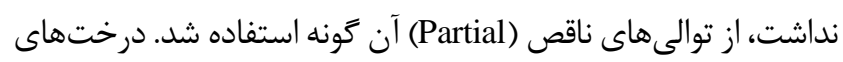

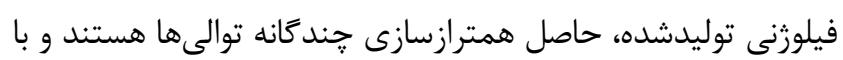

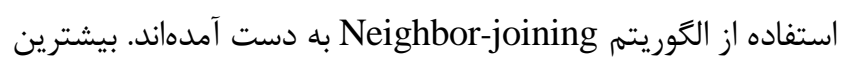
تفاوت ميان درختان RecA و RRNA مربوط به يروتئوباكترها بوده

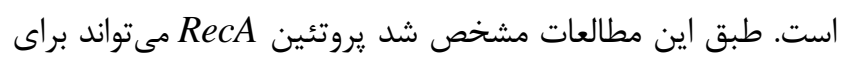

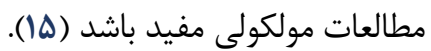

در يزوهش حاضر نيز به علت اهميت ميكروبشناسى يزشكى و مباحث تكاملى مربوط به خانوادة بروتئينى

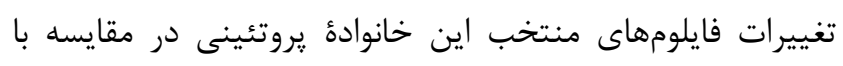

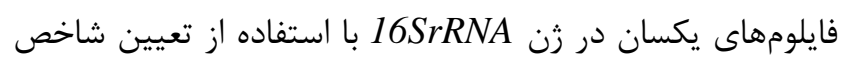
AAS

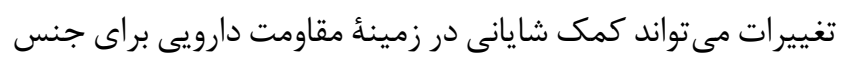
و كونهاى فايلومهاى مذكور انجام دهد.

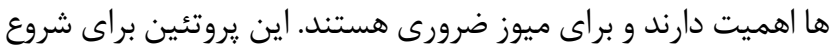

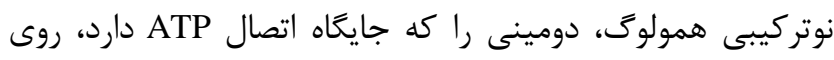

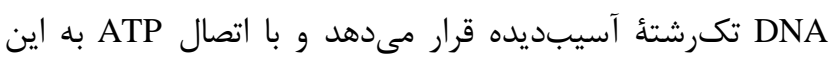

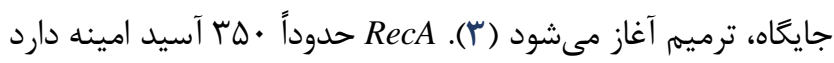

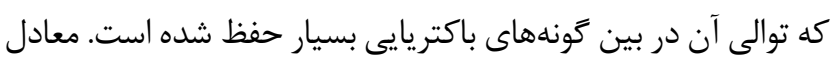

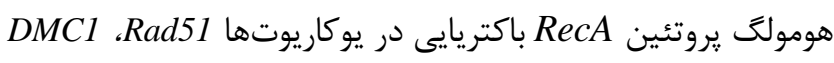

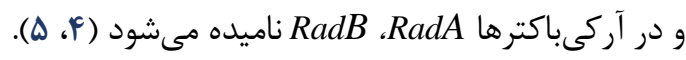
در يزوهشى كه در سال 1999 در دازشعاه استنفورد آمريكا

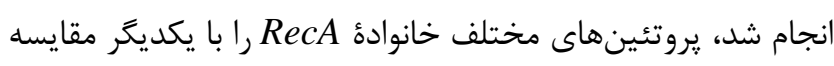

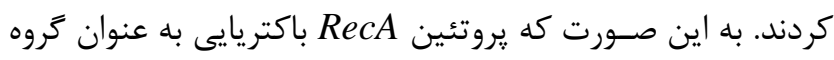
اول و DMC1/Rad51 در يوكاريوتها و RadA در آركى باكترها

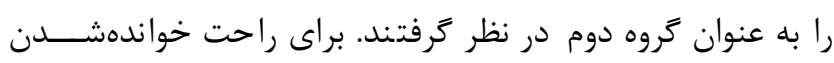

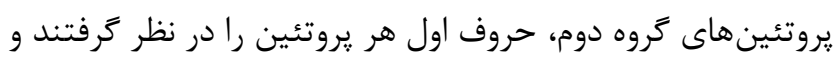

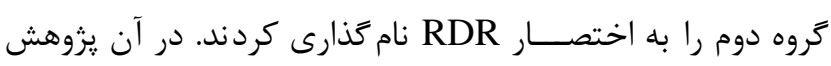

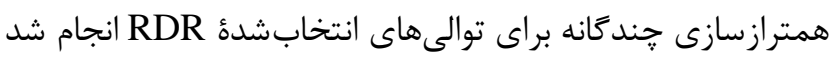

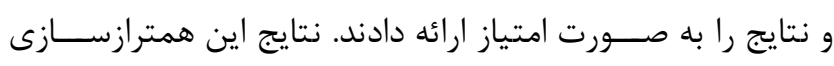
جندكانه نشان داد و بلاك (قطعهاى از توالى كه حفظ شده است)

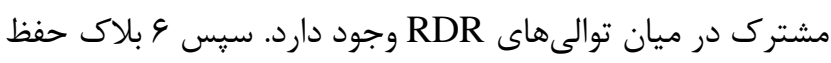

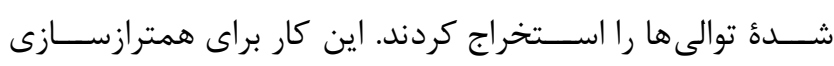

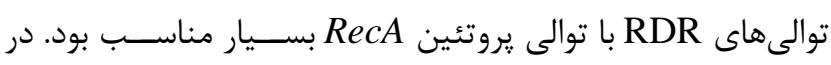

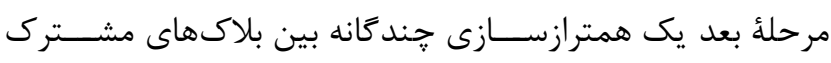

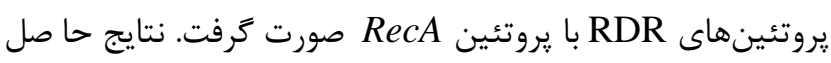

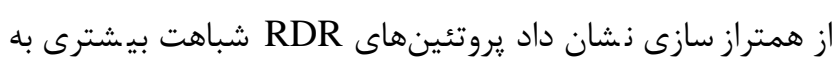

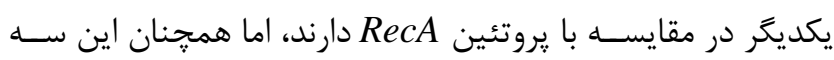

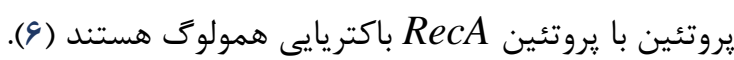

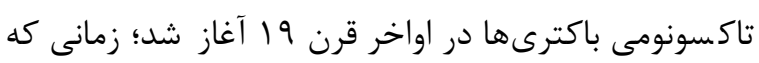

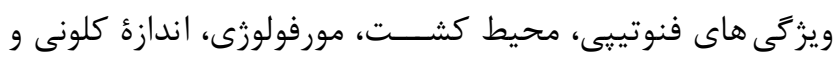

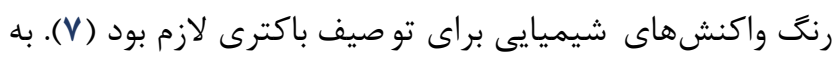

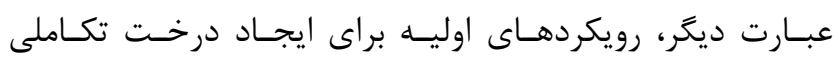

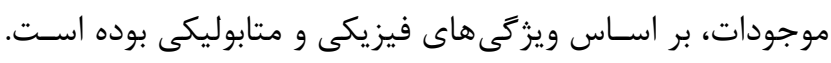

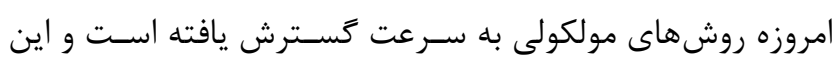

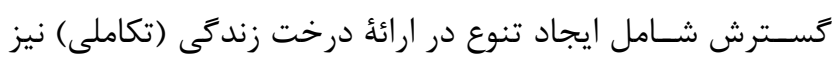

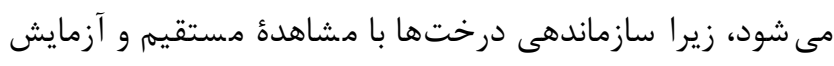

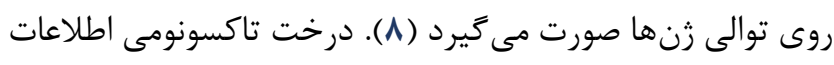

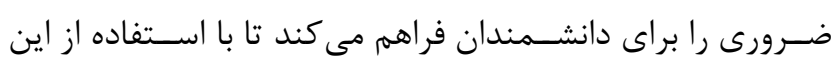

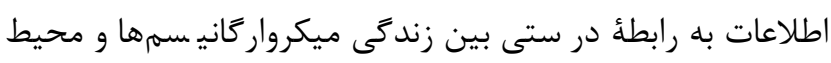

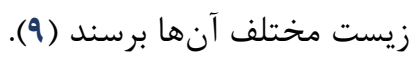


انتخاب كنيم. به اين ترتيب تعداد توالىهايى كه براى رسم درخت

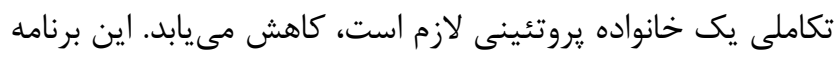

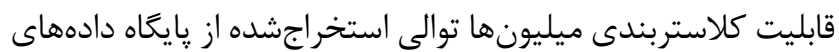
اطلاعات را دارد كه مربوط به يك خانوادة بزرى يروتئينينى هستند.

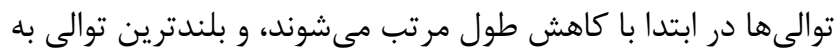

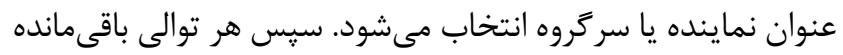

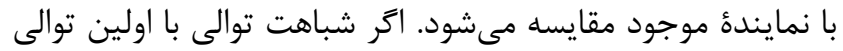

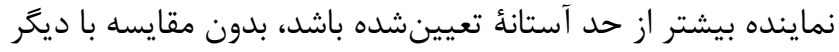

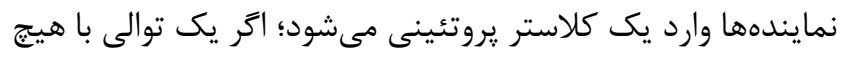

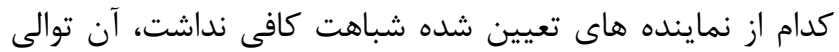
خود به عنوان يك نماينده محسوب مىشود. اين نرمافزار با استفاده

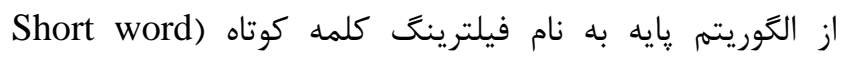
(filtering ميزان شباهت توالىها را با توجه به حد آستانهُ تعيين شده، مشخص و كلاستربندى مى كند (1)).

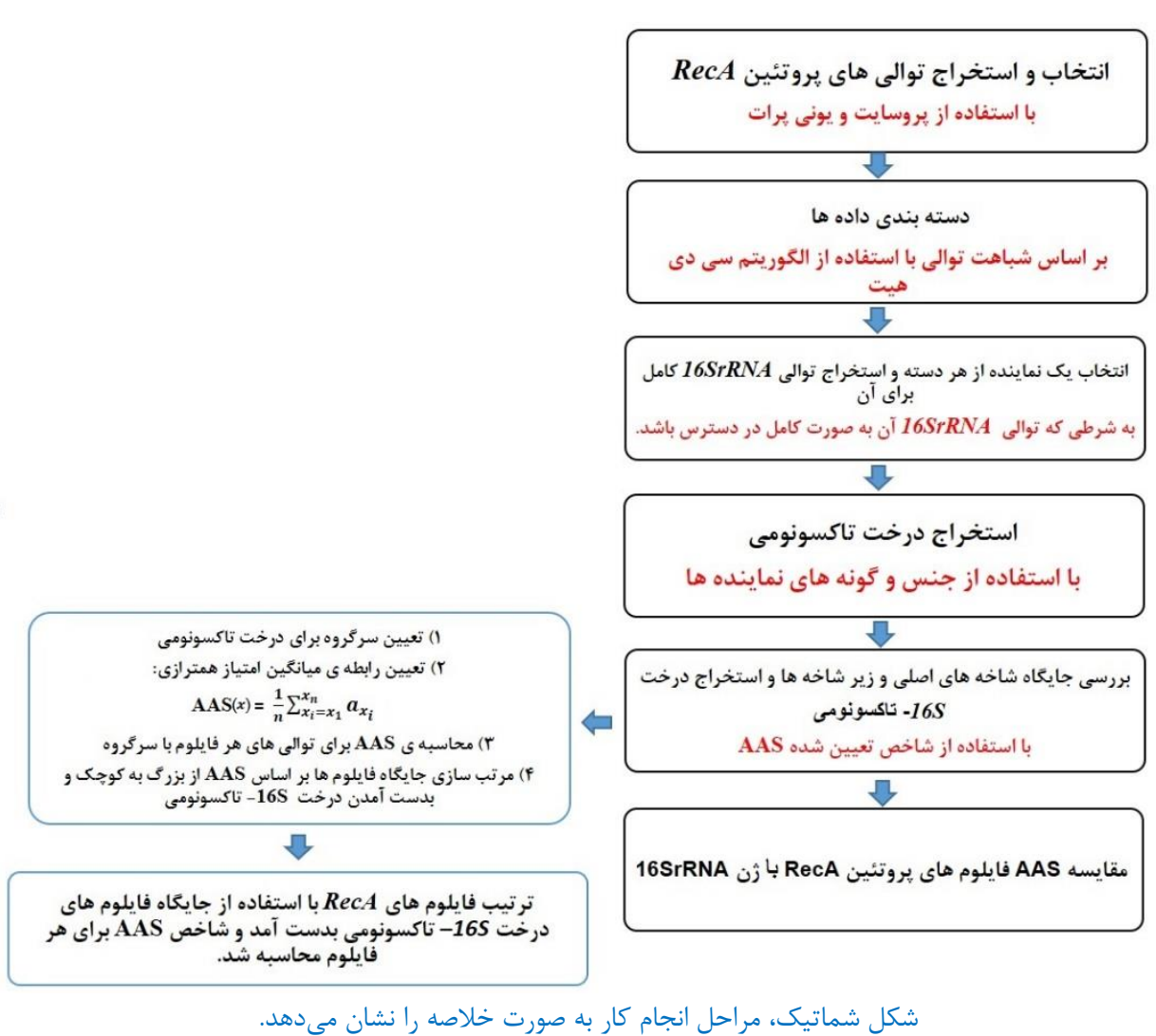

نداشتند، از ديخر اعضاى كلاستر استفاده شد. درنتيجه • ب توالى براى

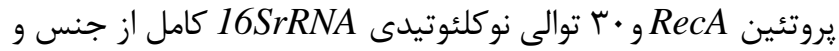

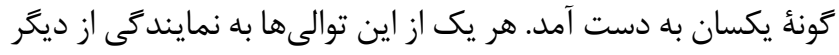

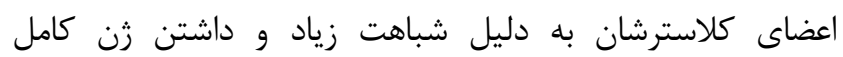
16SrRNA انتخاب شدند و باقى كلاسترها به دليل نداشتن توالى دان كامل زن 16SrRNA يا تعداد اندك توالى در كلاسترشان در اين

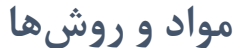

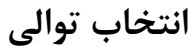

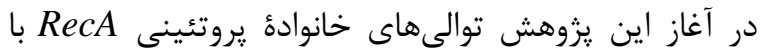

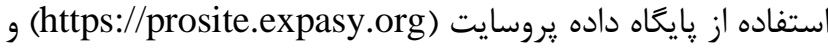

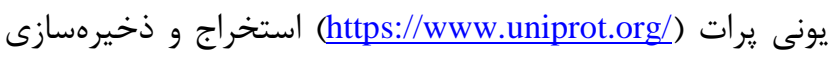
شدند (19). سيس جداسازى توالىهاى باكتريايى يروتئينى RecA

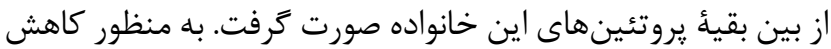
خطا در رسم درخت تكاملى با دستابندى كردن توالىها، تعداد جنس و كونههاى منتخب براى اين يزوهش محدود شد. دستابندى داى

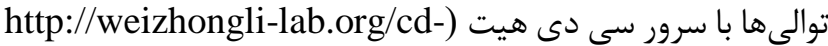
(hit/ انجام شد (IV) اين ابزار توالىهاى مشابه را در يك كلاستر

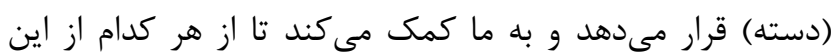
كلاسترها بتوانيم يك توالى يا يك جنس و كَونه را به عنوان نماينده آنه

انتخاب و استخراج توالى هاى يروتئين

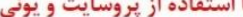

دسته بندى داده ها

بر اساس شباهت توالى با استفاده از الكوريتم سئدى دى دى V

انتخاب يك نماينده از هر دسته و استخراج توالى 16SrRNA كامل

به شرطى كه توالى 16SrRNA آن به صورت كامل در دسترس باشد.

ستخراج درخت تاكسونومى

با استفاده از جنس و كَونه هاي نماينده ها

بررسى جايكاه شاخه هاى اصلى و زير شاخه ها و استخراج درخت

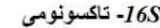

6قايسه AAS فايلوم هاي بروتئين RecA بارث

نتيجة استفاده از CD-HIT با حد آستانه DV/· براى كل توالىهاى

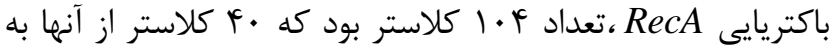
صورت تكعضوى بودند. در مرحلة بعد سرگروههاى مربوط به هر

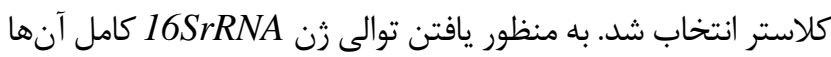

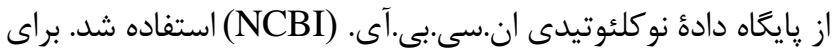

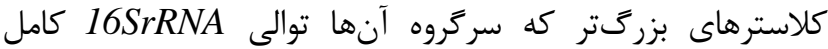


امتياز همترازسازى (AAS) براى توالىهاى يروتئينى RecA در فايلومها

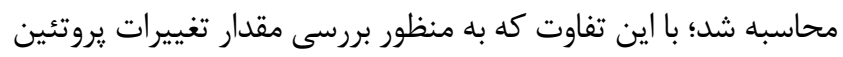

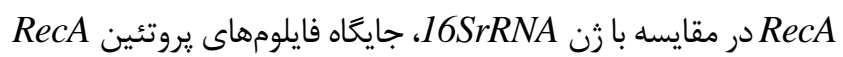
هماند فايلومهاى درخت 16S-تاكسونومى در نظر كرفته شد.

يافتهها

همانطور كه در بخش روش كار قسمت انتخاب توالى توضيح

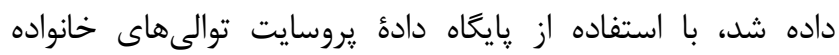

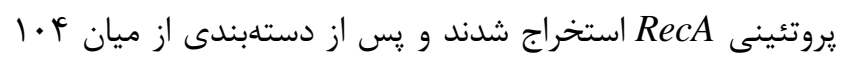

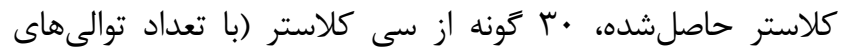

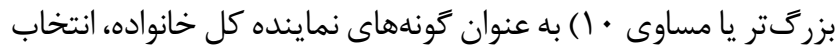

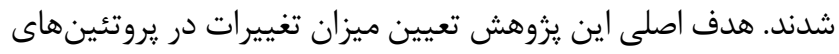

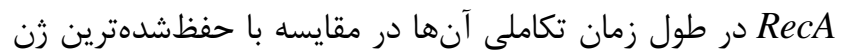

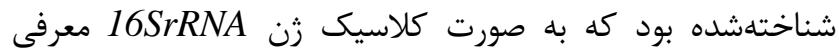

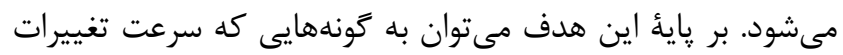

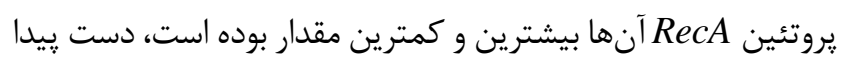
كرد. به اين ترتيب مىتوان تعيين كرد سرعت تغييرات براى زن

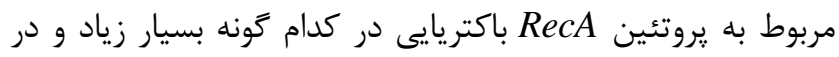

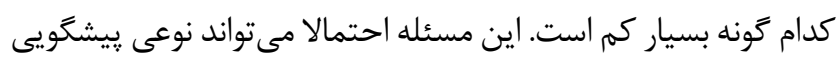
براى يكى از دلايل ايجاد مقاومت باكترىها به داروها طى زمان إنى طولانى باشد. به طور اساسى تعيين ميزان تغييرات در طول تكامل

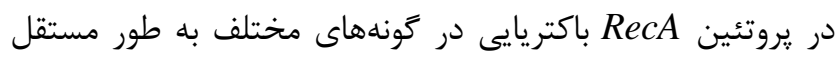

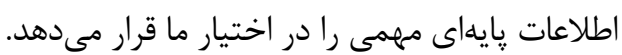

\section{درخت تاكسونومى حاصل براى • ب كَنهُ انتخابى}

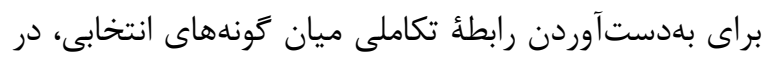

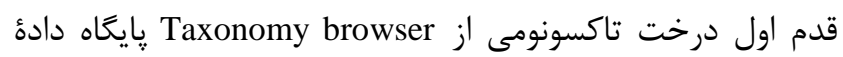
استخر اج شد. شكل ا درخت تاكسونومى مربوط به • بَ مونهٔ

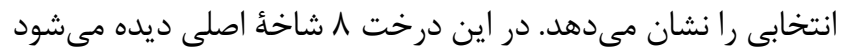

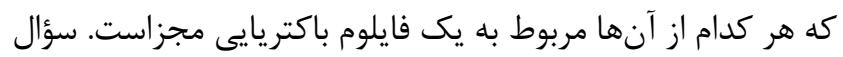

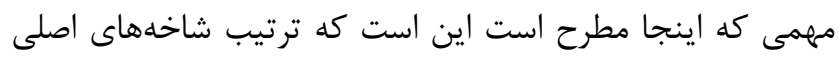

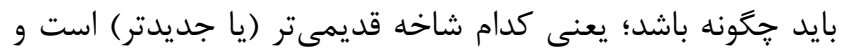

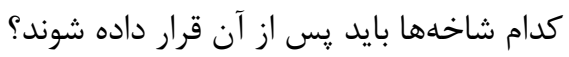
براى اصلاح ترتيب شاخههاى اصلى درخت تاكسونومى، بايد يك قاعدة مناسب تعيين شود. به اين منظور از توالى كامل

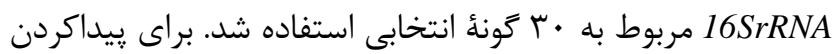
و استفاده از يك قاعده مناسب مراحل زير به ترتيب انجام شد:
يززوهش استفاده نشدند.

استخراج درخت تاكسونومى و محاسبه درخت 9 الس اسن تاكسونومى براى • ب كَونة انتخابى تاكي

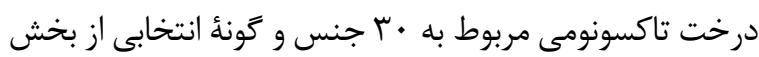
NCBI Taxonomy Browser صحت جايكاه تكاملى هر كدام از شاخههاى اصلى و زيرشاخههاى

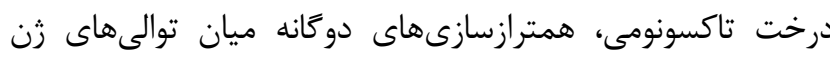
16SrRNA درونشاخهاى و بينشاخهاى صورت ترفت. براى اين

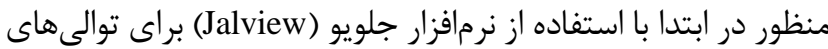

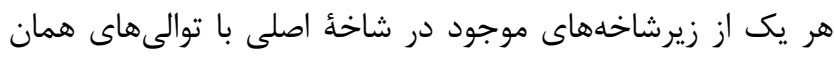
شاخه همترازسازى دو كانه انجام شد. در ادامه مشخص داخد شد هد هر كدام از شاخههاى اصلى درخت تاكسونومى مربوط به يك فايلوم (Phylum)

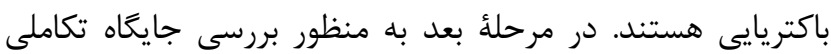

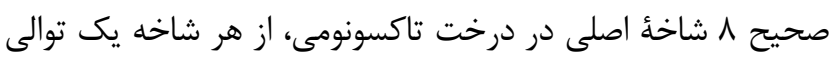

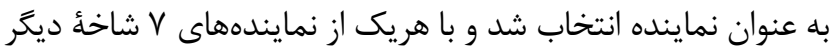

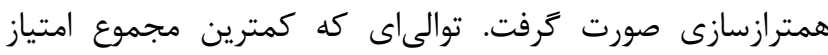
همترازسازى را نسبت به مجموع امتياز همترازسازى ديكر نمايندهـها

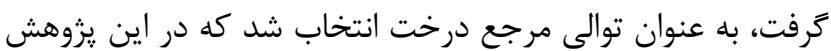

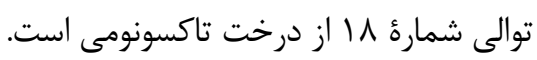

\section{محاسبة شاخص ميانگين امتياز همتراز يهمنظور تعيين} جينش شاخههاى اصلى در درخت تاكسونومى مئى

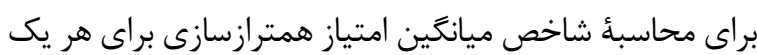
از V شاخؤ اصلى درخت تاكسونومى از رابطؤ زير استفاده شد. $\operatorname{AAS}(\mathrm{x})=\frac{\mathbf{1}}{\boldsymbol{n}} \sum_{x_{i}=x_{1}}^{x_{n}} a_{x_{i}}$ در اين رابطه AAS مخفف Average Alignment Score و

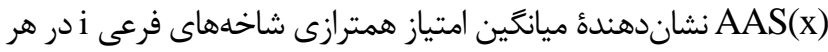

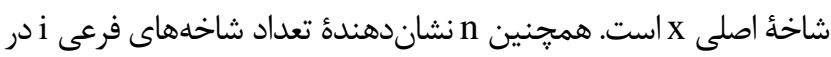

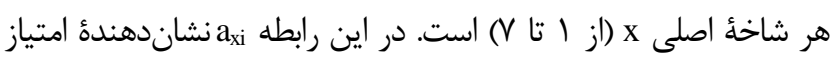
همترازى هر شاخه فرعى i در يك شاخئ اصلى x با توالى مرجع است. توالى مرجع درخت، توالى زن 16SrRNA كامل از جنس و كونة Bacteroides fragilis است كه بر اساس همترازى هايى كه در

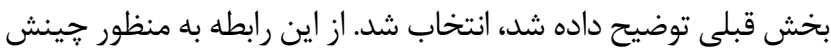

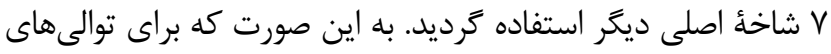

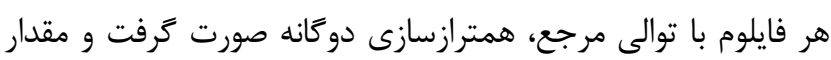

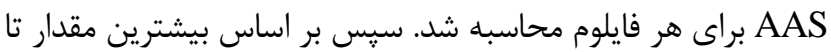
كمترين مقدار AAS، فايلومها در ساختار درخت مرتب شدند. نتيجه بلدستآمده درخت S|S|-تاكسونومى ناميده شد. در ادامه ميانكَين 
دليل تكتوالىبودن در اين محاسبه استفاده نشد.

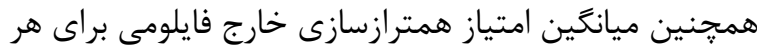

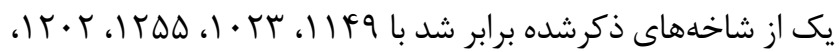

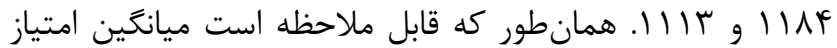

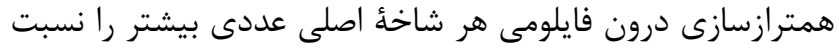

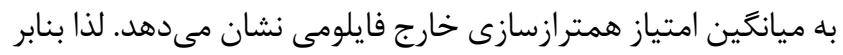
نتايج اولين و دومين بررسى، به طور نسبى مى توان كفت كه در اين درخت تاكسونومى، شاخههاى فرعى در هر شاخذ اصلى، به طور صحيحى قرار گرفتند. ז. بررسى صحت جايگاه تكاملى هر شاخئ اصلى در درخت

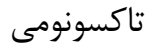

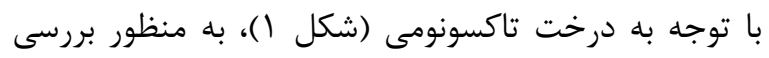
جايگاه شاخههاى اصلى كه آيا از نظر تكاملى ترتيب درستى دارند

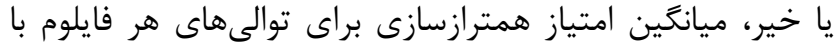

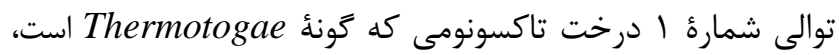
محاسبه شد و نتيجأ آن در شكل ب قابل ملاحظه است.
I. كسب اطمينان از صحيحبودن جايكاه تكاملى شاخههاى

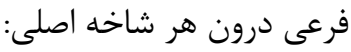
به اين منظور دو بررسى صورت گرفت. در اولين بررسى،

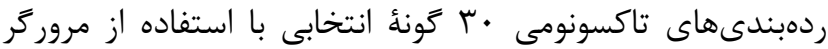
تاكسونومى ان.سى.بى.آى. (NCBI Taxonomy Browser)

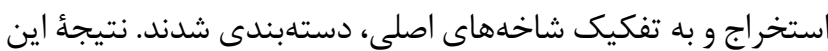
بررسى در شكل r قابل مشاهده است. همانطور كه در شكل بأل ديده مىشود، كونههاى موجود در هر شاخئ اصلى، حداقل از بخش

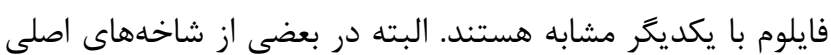
ميزان اين شباهت تا ردههاى پايينتر ادامه يِيدا مى كند. 16SrRNA در دومين بررسى ميزان شباهت توالىهاى زن

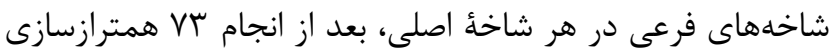
محاسبه شد. نتايج اين بررسى به اين صورت به دست آمد كه

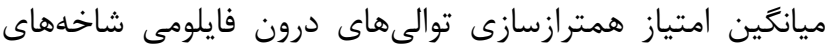

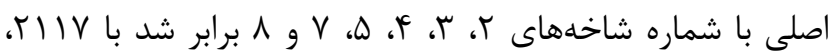

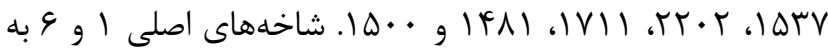

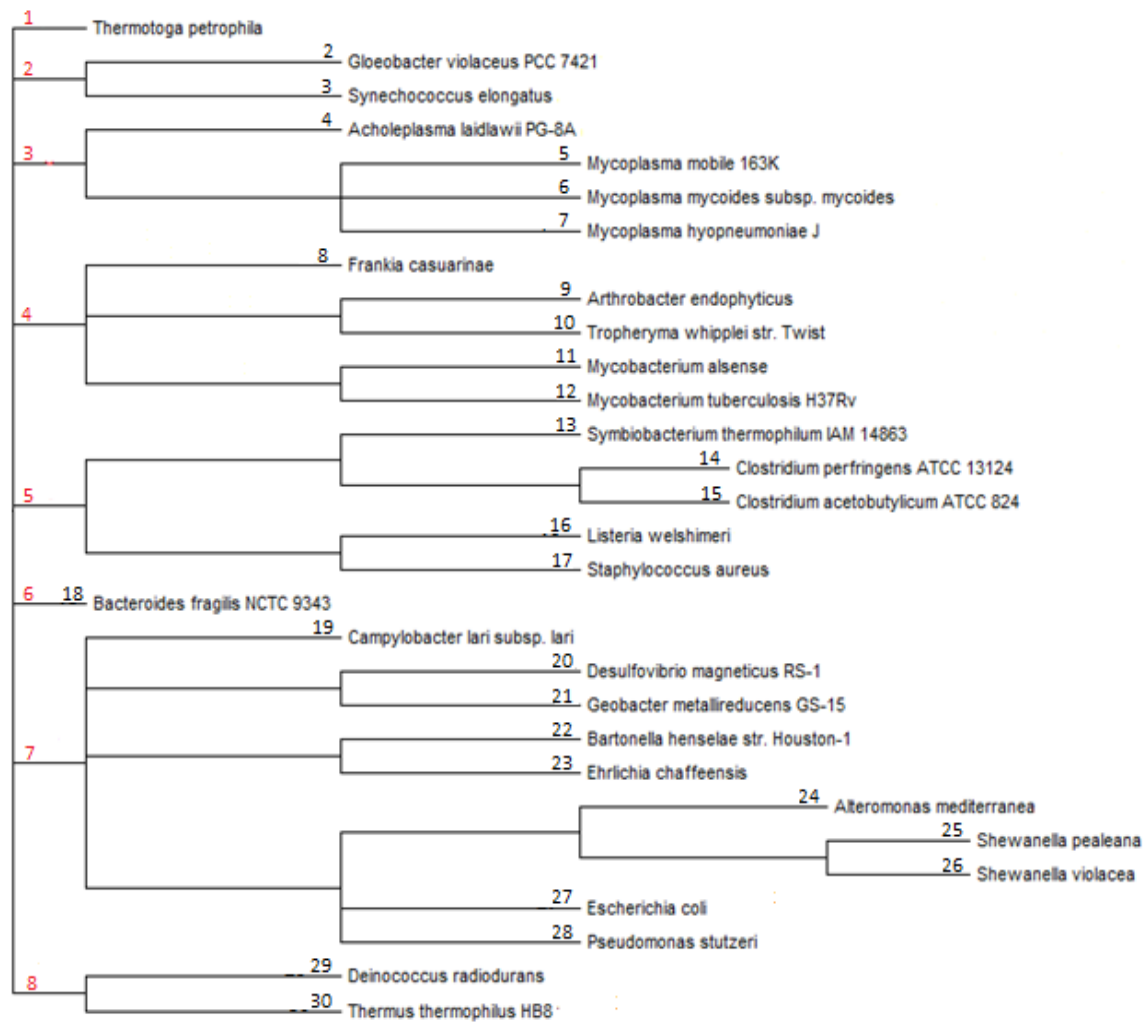

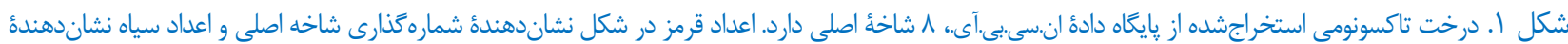

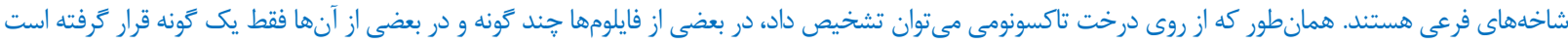




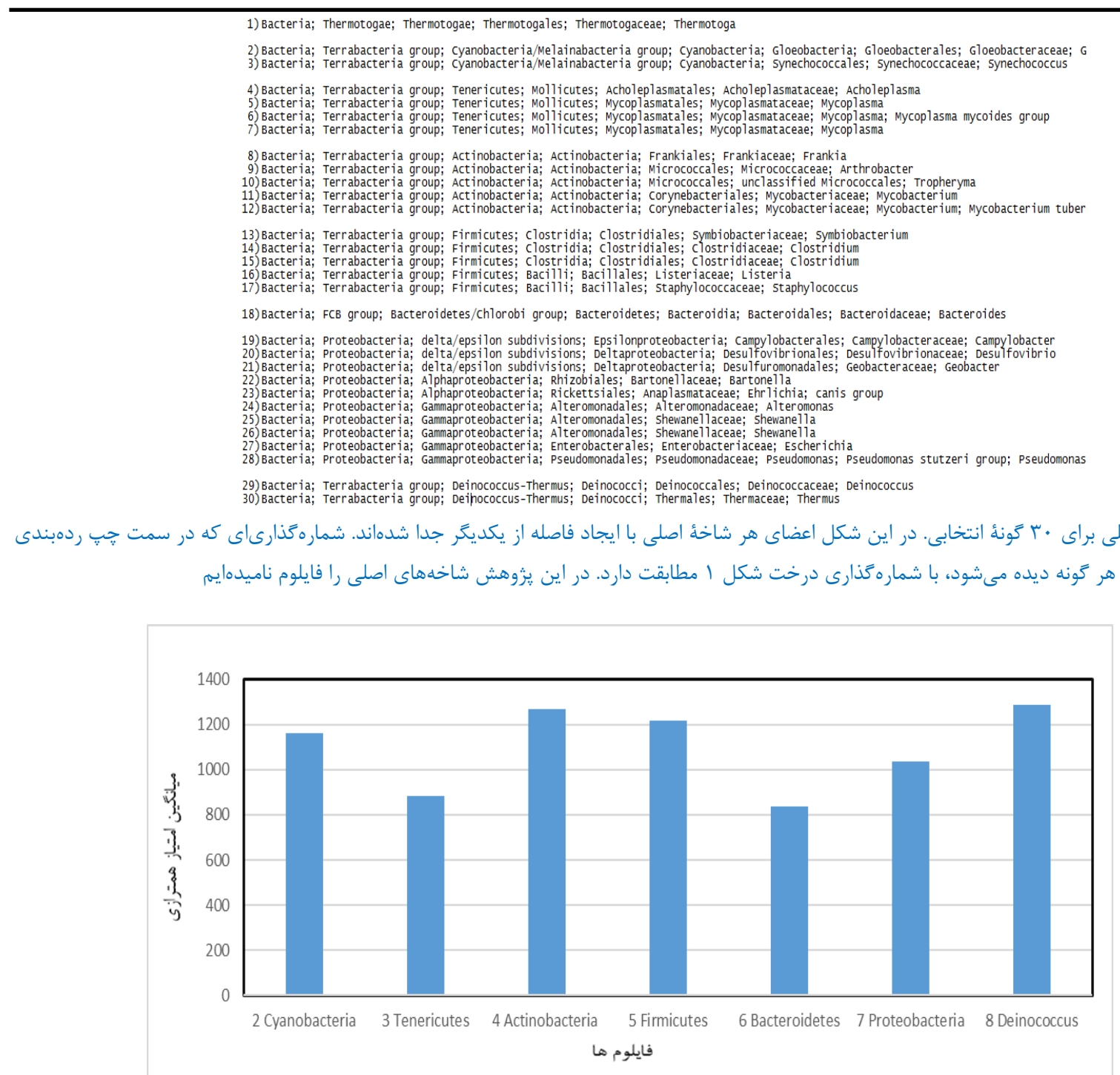

شكل r. نمودار ميانگين امتياز همترازسازى براى توالىهاى هر فايلوم با توالى شماره ال (كونه هhermotogae) در درخت تاكسونومى (شكل ().

درخت تاكسونومى مرتب شدند. حاصل اين جينش درخت 16S-

$$
\text { تاكسونومى ناميده شد (شكل س). }
$$

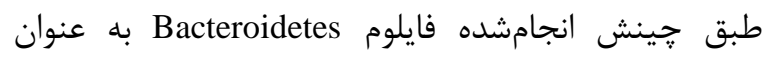
سرگروه درخت انتخاب شد و يس از آن به ترتيب فايلومهاى شماره دو: Actinobacteria ، سه: Firmicutes، جهار: Cyanobacteria، گنج:

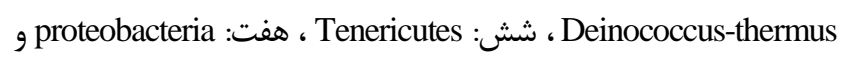
آخرين فايلوم Thermotogae قرار گرفتند. فايلوم يا شاخه اصلى سلى

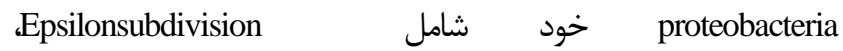
Glphaproteobacteria

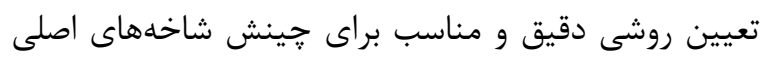

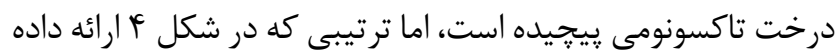
شده است، بر مبناى زن 16SrRNA است و مى تواند نتيجهاى بهتر

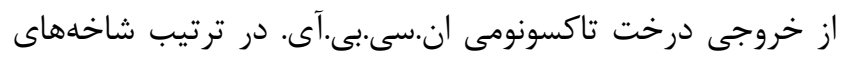

با توجه به نمودار قابل مشـاهده در شـكل r مىتوان دريافت كه نمودار، روند كاهشــى (يا افزايشــى) را دنبال نمى كند و اين

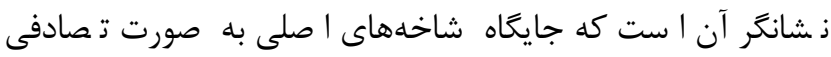
تعيين شده است و بر اساس روند تغييرات تكاملى نيست.

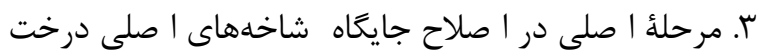
تاكسونومى

همانطور كه در بخش روش كار توضيح داده شد، با استفاده از شاخص AAS ميانگين امتياز همتراز سازى توالىهاى هر فايلوم

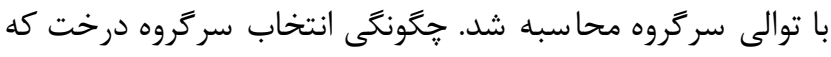
توالى شمارة 1) (با جنس و گونه تاكسونومى است در بخش سوم روش كار توضيح داده شده است. فايلومى كه بي شترين مقدار AAS را دا شت، بعد از توالى سرگروه

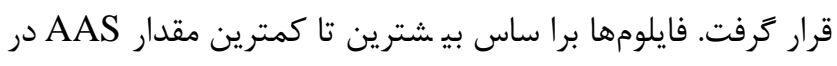


آوردن درختهاى فيلوزنى مانند الخوريتم neighbour joining و UPGMA

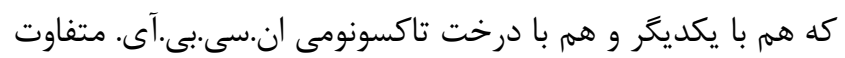

اصلى به ما بدهد. ترسيم يك درخت تكاملى صحيح كه ارتباط دقيق

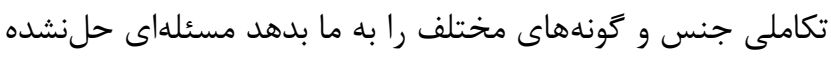

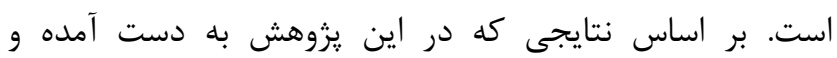
بررسىهايى كه انجام شده است، الخوريتمهاى موجود براى بلدست

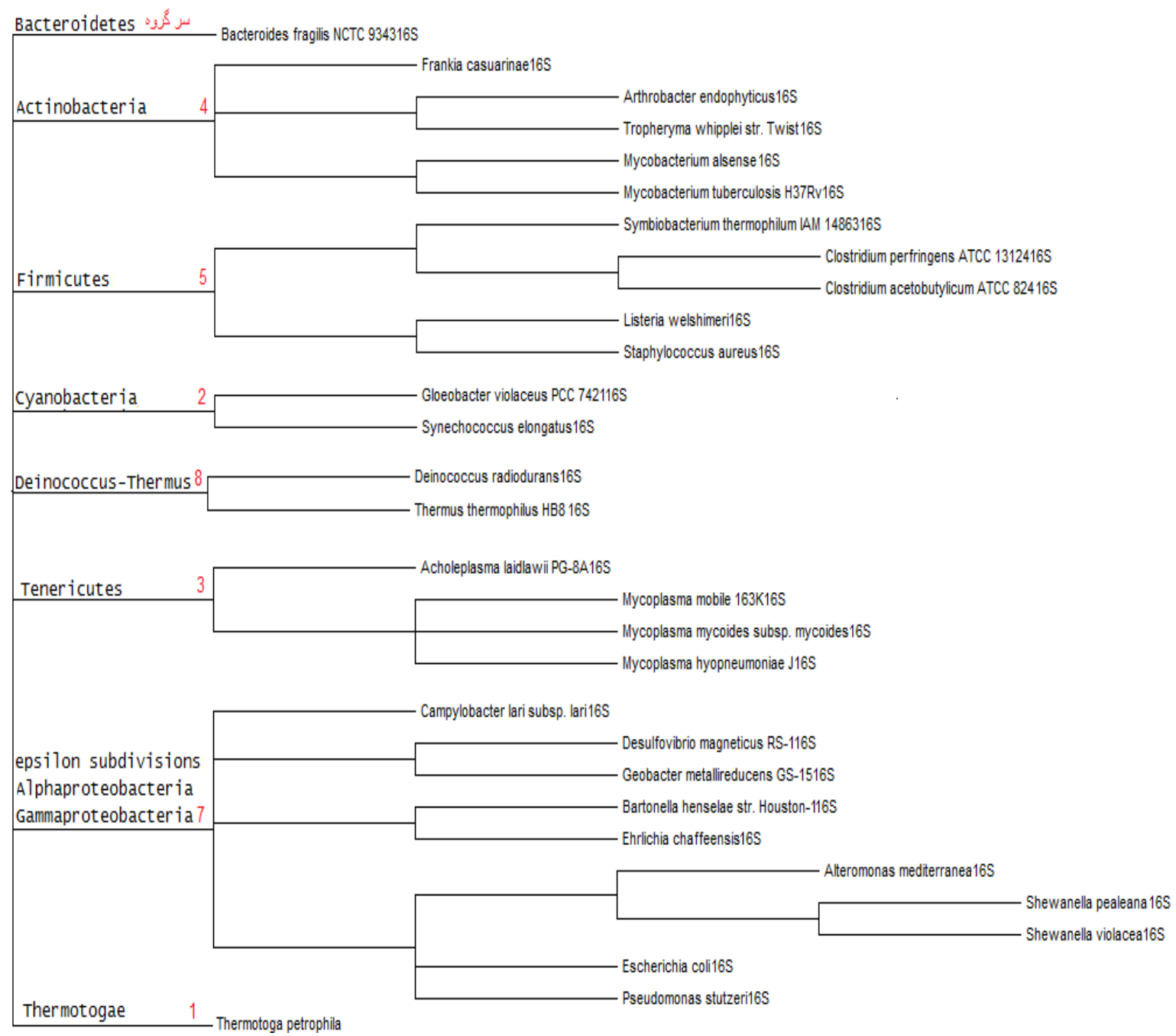

شكل ع. درخت 16S-تاكسونومى: اين درخت بر اساس ميانكين امتياز همترازى (AAS) شاخههاى فرعى هر فايلوم با فايلوم سركروه به دست آمده است.

از سركروه فاصله مى گيرند، ميزان شباهت و امتياز آنها كمتر مىشود.

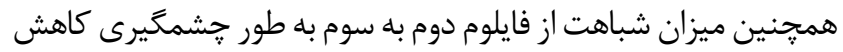
يافته است كه اين امر بيانكر تغييرات شديد تكاملى در اين فايلومها است. در ادامه براى توالىهاى يروتئين RecA محاسبات مشابه با موارد توضيحدادهده براى زن 16SrRNA انجام شد.

\section{آناليز توالىهاى بروتئينى RecA براى تعيين فاصله تكاملى}

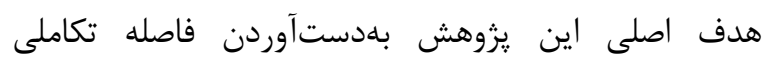
توالىهاى منتخب RecA از خانواده يروتئينى RecA در مقايسه با تردئ
نمودار شكل ه، متوسط امتياز همترازسازى توالىهاى هر فايلوم با فايلوم سرگروه يعنى AAS را براى درخت 16Sتاكسونومى نشان مى دهد. همانطور كه انتظار مىرفت نمودار سير نزولى را دنبال مى كند و فايلوم Thermotogae با كمترين ميزان

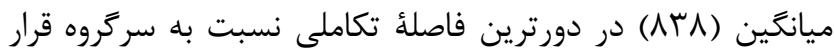

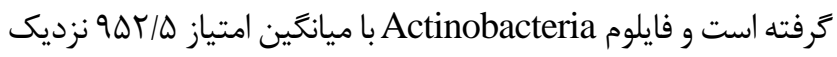
ترين فايلوم به سرگروه است كه نشاندهنده شباهت بيشتر اين فايلوم از نظر تكاملى با سرگروه است. اين روند نشان داده است هرجه توالىها 


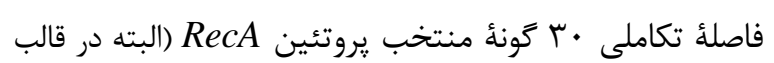
1 فايلوم) در مقايسه با زن 16SrRNA تغييرات زيادى رانشان مى دهدي. اين مسئله بيانكر آن است كه ميزان تغييراتى كه در يروتئين

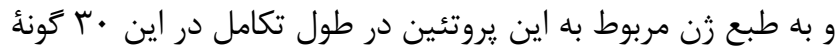

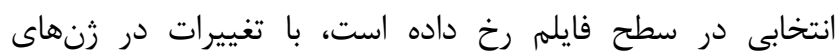

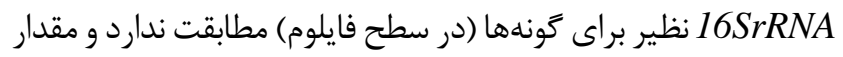
متفاوتى را نشان مىدهد. ميزان اين تغييرات در جدول الو و نمودار

$$
\text { شكل و مشخص شده است. }
$$

توالىهاى رن 16SrRNA همان جنس و كونهها بوده است. به اين منظور توالىهاى يروتئينى RecA با كونه يكسان با زنهاى

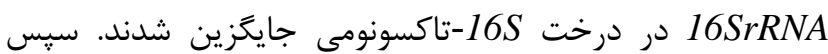
توالىهاى آمينواسيدى هر فايلوم با توالى فايلوم سركروه (Bacteroides) شد. شتايح حاصل از اين محاسبات براى نمايندههاى خانواده (بخش باكتريايى) در شكل و قابل ملاحظه است.
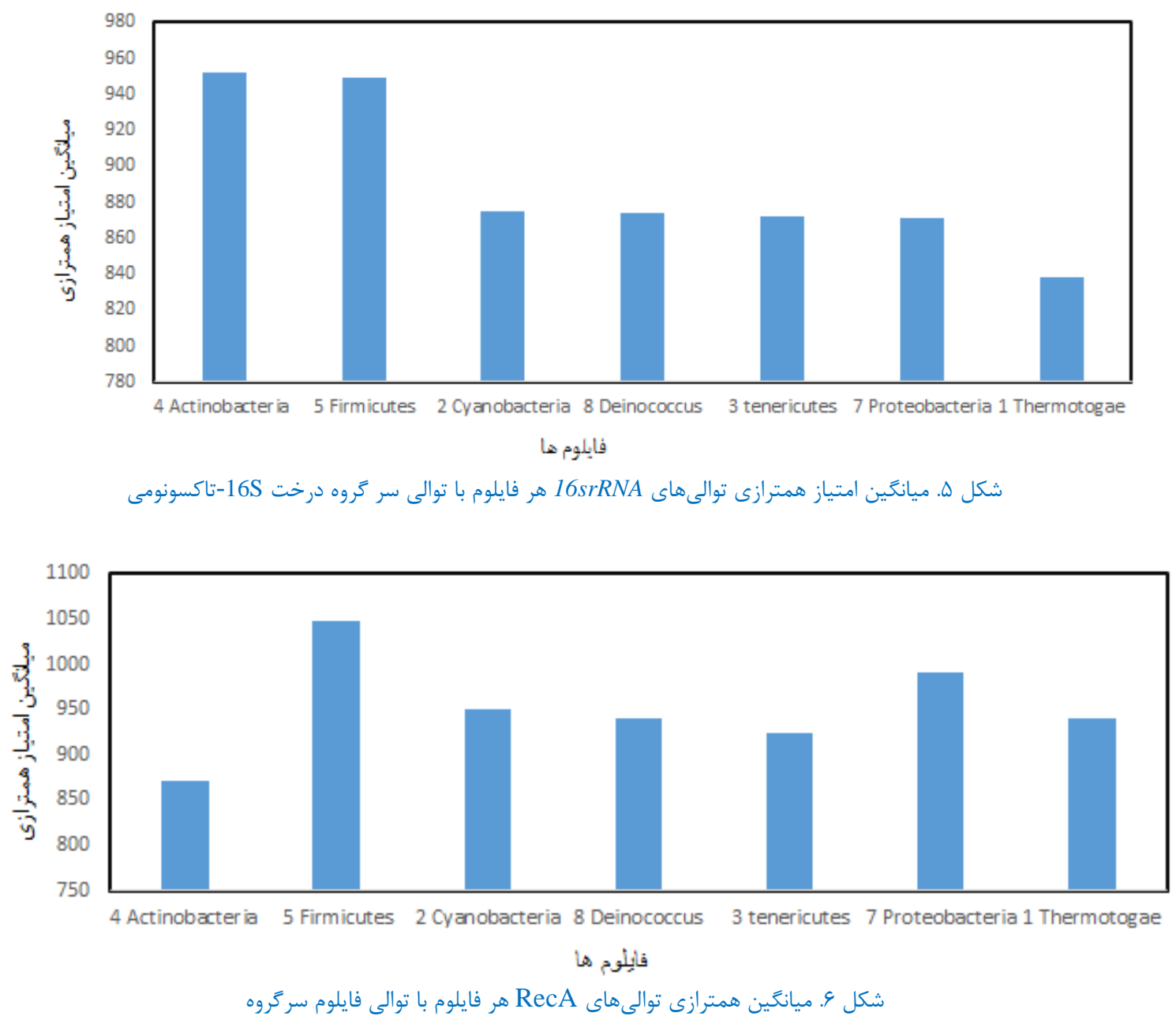

Actinobacteria تغييرات RecA در طول تكامل در فايلومهاى مختلف سرعتهاى

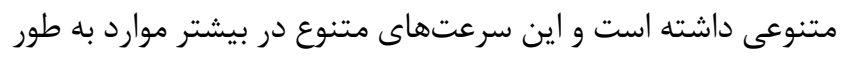
كلى تفاوتهاى اساسى با الكَوى تغييرات در زنهاى 16SrRNA نظير دارد. فايلوم بعدى كه دستخوش بيشترين تغييرات شده است،

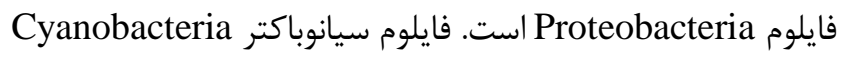
در هر دو درخت جايكاه ثابت دارد. فايلومهاى Deniococcus و
همانطور كه در شكل \& قابل ملاحظه است، فايلوم Actinobacteria

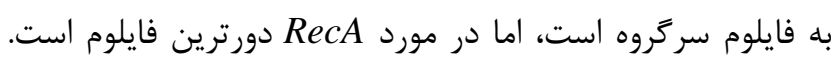
اين مسئله نشان مىدهد زن RecA در فايلوم Actinobacteria دره مقايسه با زن 16SrRNA تغييرات بسيار بيشترى در طول تكامل

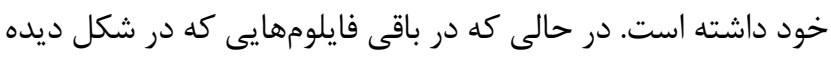

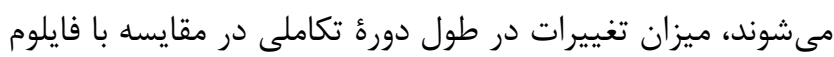




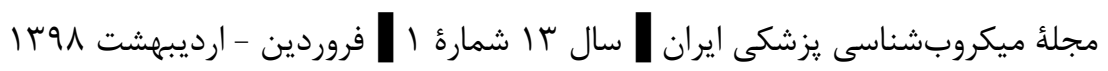

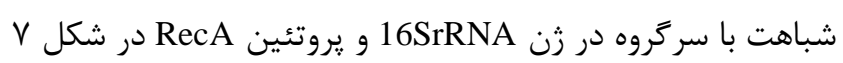
نشان داده شده است.
Tenericutes

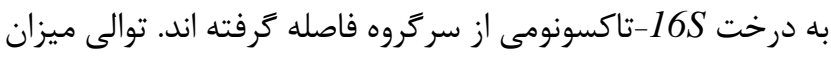

جدول ا. مقدار AAS محاسبهشده براى فايلومهاى زن 16SrRNA و يروتئين RecA

\begin{tabular}{|c|c|c|}
\hline مقدار AAS براى توالى هاى بروتئينى & 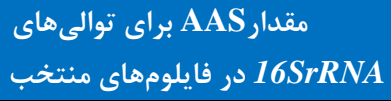 & اسامى فايلومها \\
\hline$\wedge \vee$. & $9 \Delta r$ & Actinobacteria \\
\hline $1 . F V$ & $q q q$ & Firmicutes \\
\hline$q f q$ & $\Lambda V F$ & Cyanobacteria \\
\hline qf. & $\Lambda V F$ & Deinococcus \\
\hline$q F F$ & AVr & Tenericutes \\
\hline 991 & $\wedge \vee 1$ & Proteobacteria \\
\hline$q 41$ & ArA & Thermotogae \\
\hline
\end{tabular}

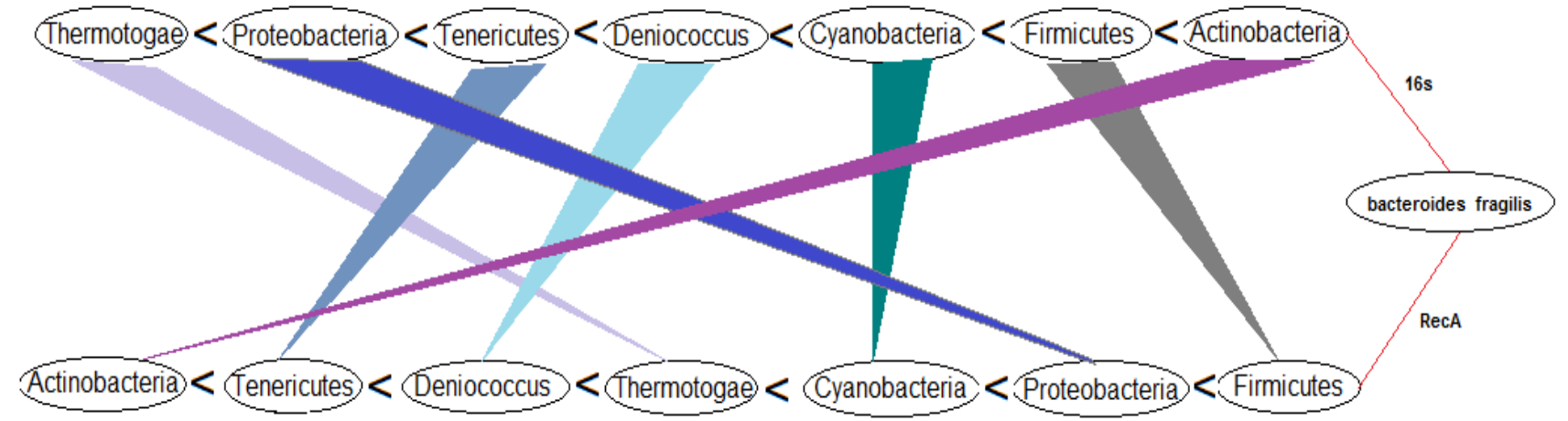

شكل V. نامعادلة تعيينشده بر اساس محاسبات AAS در فايلومهاى منتخب براى توالىهاى 16SrRNA و توالىهاى يروتئينى RecA

جديد گونههاى مايكوباكتريوم از شباهت توالىهاى نوكلئوتيدى

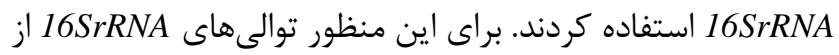
كونه هاى مختلف مايكوباكتريوم را همترازسازى كردند كه نتيجه

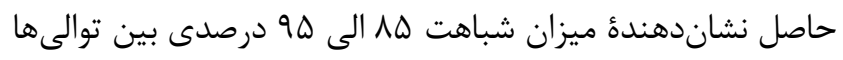

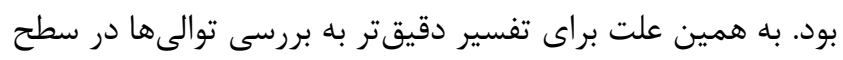

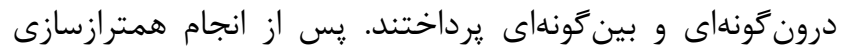

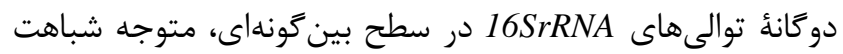
ه9 الى 91 درصدى در خانوادة مايكوباكتريوم شدند. همجنين

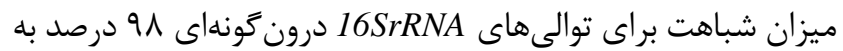

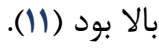

در اين يزوهش نيز ما به بررسى روند تكاملى خانواده يروتئينى

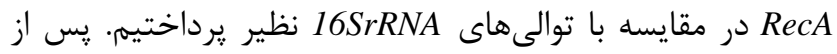

\section{بحث و نتيجهَ كيرى}

مقايسه نتايج فيلوزنتيك براى جانداران مشخص بـ بإئ استفاده از

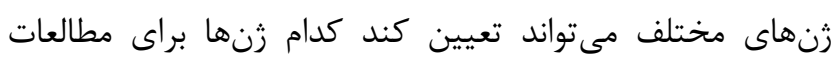

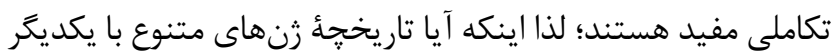

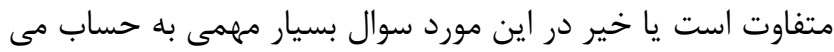

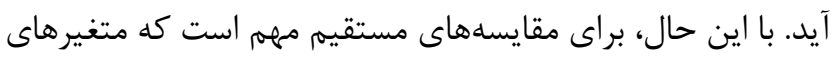

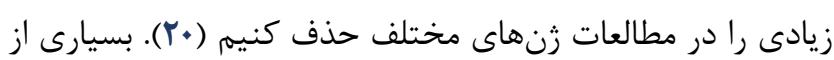

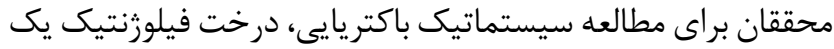

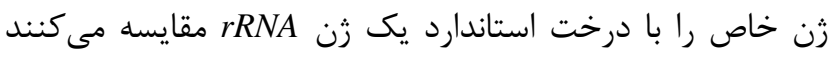

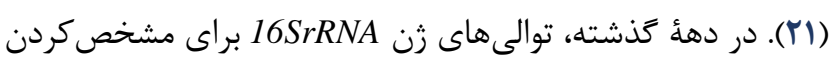

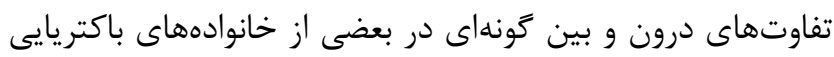

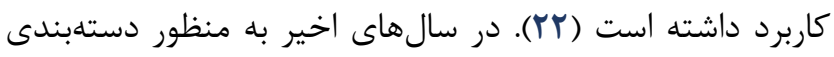


به اين صورت كه وقتى نرخ تغييرات طى تكامل براى گَونهاى بيشتر

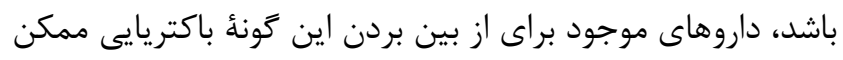

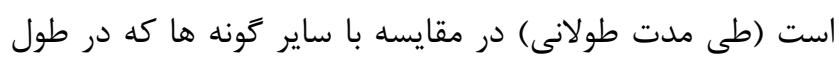
تكامل تغييراتشان كندتر بوده، زودتر ناكار آمد شوند. با توجه به اهميت روند تكاملى و تغييرات باكترىها و زنهاى

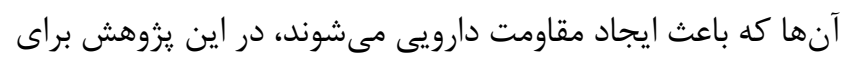

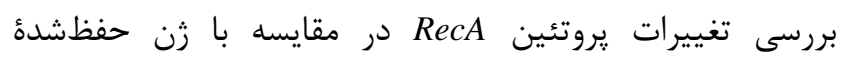

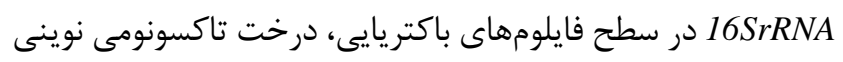

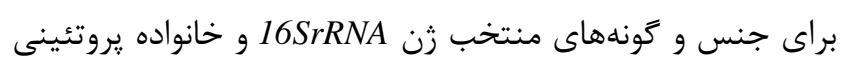
RecA متفاوت است. درنهايت بر اساس محاسبات انجام شده داست در اين اين

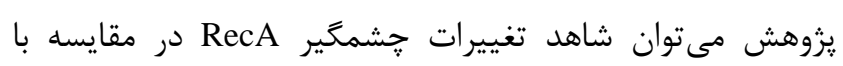
16SrRNA در طول تكامل در فايلوم Actinobacteria

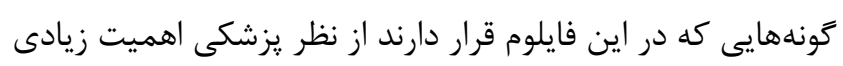

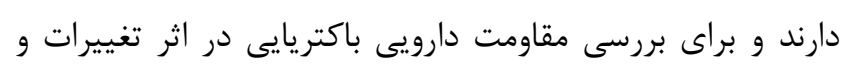

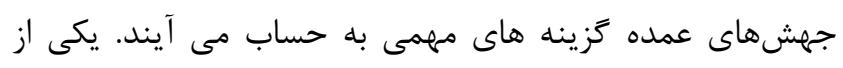
جنس و كَونهاى شناختهشده در اين فايلوم Tuberculosis

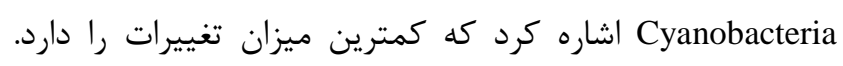

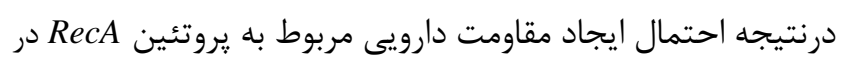

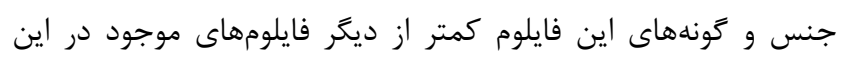

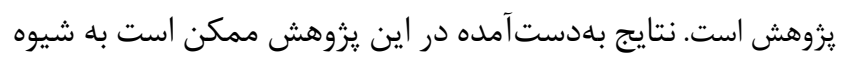

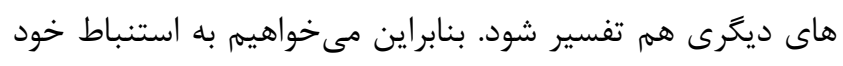

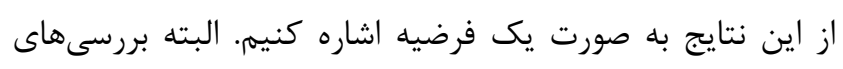

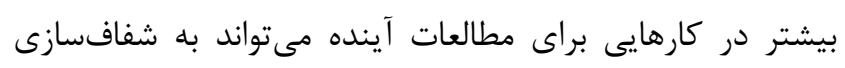
بيشتر اين استنباط كمك كند.

بايد اشاره كنيم نزديكترين مقاله به يزوهش حاضر كارى است

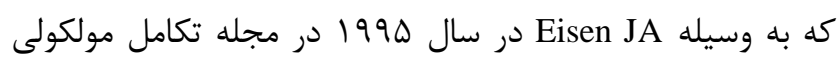

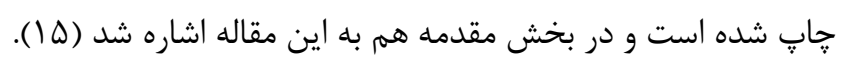

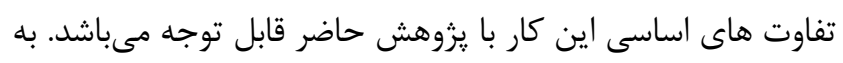

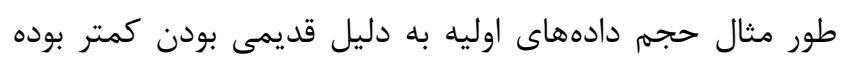

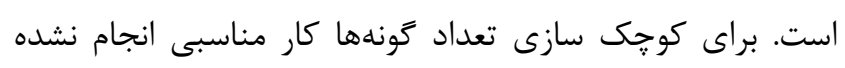

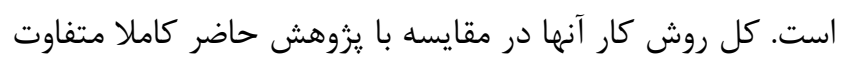

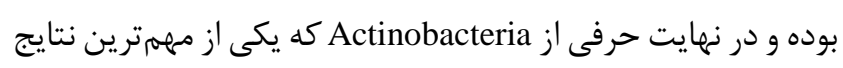

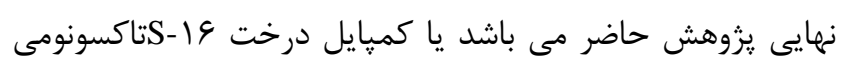

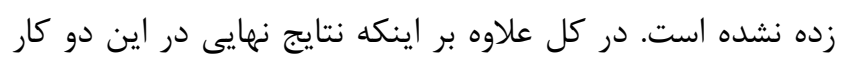

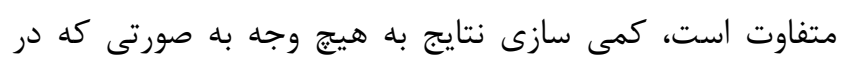

استخراج درخت تاكسونومى و قرار دادن توالىهاى 16SrRNA براى

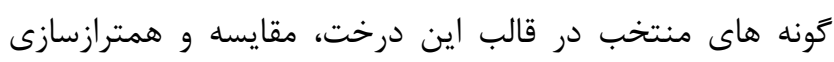

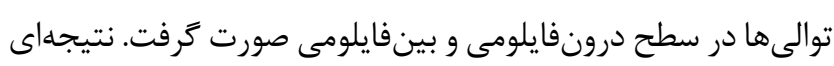

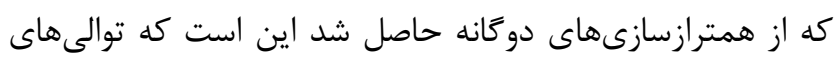
16SrRNA

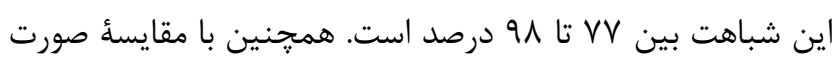

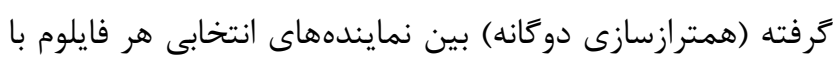

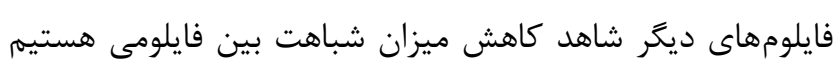
(ميزان شباهت بين وع تا الو 1 درصد است).

در ديخر مطالعات انجام شده براى بررسى توالىهاى 16SrRNA در مقايسه با زن RecA

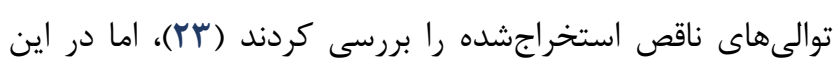

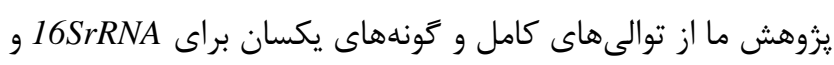

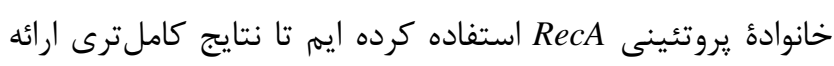

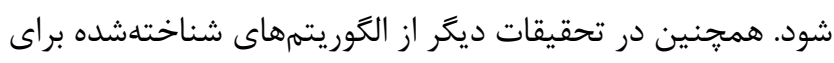

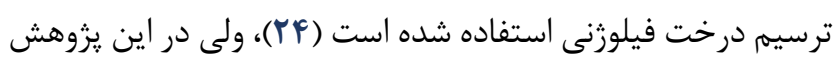

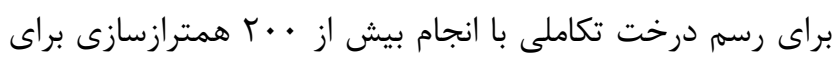

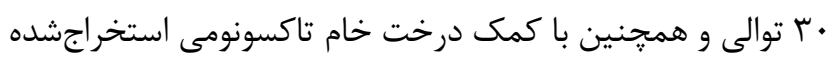

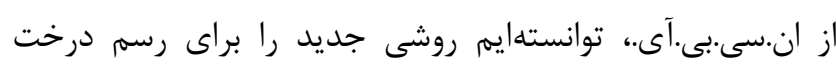

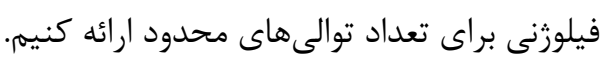

در اين يزوهش، يّ از انجام محاسبات لازم و اصلاح جايعاه

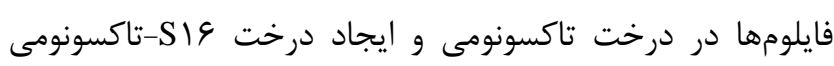

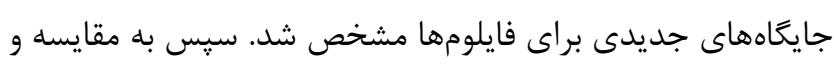

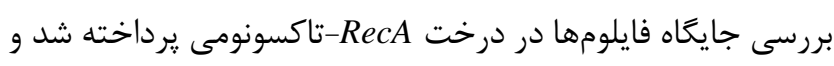

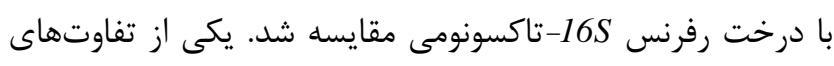

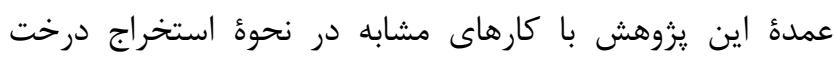

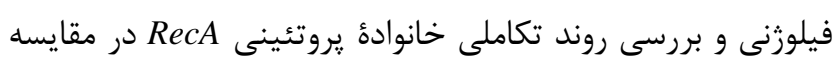

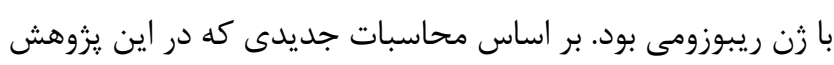

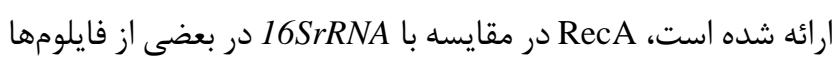
طى روند تكاملى تغييرات بسيار زيادى داشته است. جايكاه فايلوم Cyanobacteria در شكل V ثابت است كه

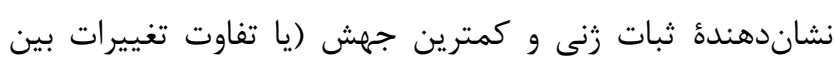

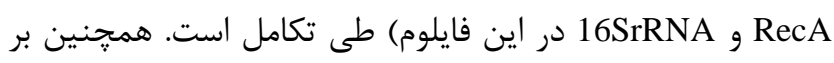
اساس محاسباتى كه در اين يزوهش انجام شده است، بيشترين

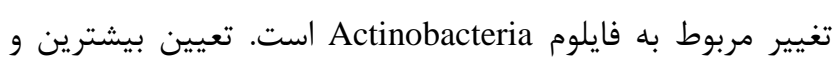

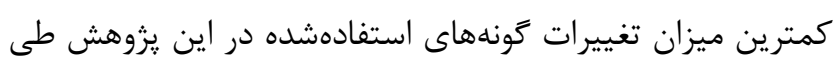
روند تكاملى براى بررسى مقاومتهاى دارويى نيز نيز حائز اهميت است. 


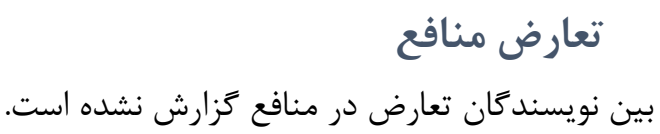

\section{References}

1. Taghizadeh M, Khoei S, Nikoofar AR, Ghamsari L, Goliaei B. The Role of Rad51 Protein in Radioresistance of Spheroid Model of DU145 Prostate Carcinoma Cell Line. International Journal of Radiation Research. 2009; 7(1):19.

2. Chintapalli SV, Bhardwaj G, Babu J, Hadjiyianni L, Hong Y, Todd GK, et al. Reevaluation of the Evolutionary Events Within RecA/RAD51 Phylogeny. BMC Genomics. 2013; 14(1):240.

3. Wang TF, Chen LT, Wang AH. Right or Left Turn? Reca Family Protein Filaments Promote Homologous Recombination Through Clockwise Axial Rotation. Bioessays. 2008; 30(1):48-56.

4. Shinohara A, Ogawa H, Ogawa T. Rad51 Protein Involved in Repair and Recombination in S. Cerevisiae is a RecA-Like Protein. Cell. 1992; 69(3):457-470.

5. Bishop DK, Park D, Xu L, Kleckner N. DMC1: A MeiosisSpecific Yeast Homolog of E. Coli RecA Required for Recombination, Synaptonemal Complex Formation, and Cell Cycle Progression. Cell. 1992; 69(3):439-456.

6. Brendel V, Brocchieri L, Sandler SJ, Clark AJ, Karlin S. Evolutionary Comparisons of RecA-Like Proteins Across All Major Kingdoms of Living Organisms. Journal of Molecular Evolution. 1997; 44(5):528-541.

7. Hug LA, Baker BJ, Anantharaman K, Brown CT, Probst AJ, Castelle CJ, et al. A New View of the Tree of Life. Nature Microbiology. 2016; 1(5):16048.

8. Gevers D, Cohan FM, Lawrence JG, Spratt BG, Coenye T, Feil EJ, et al. Re-Evaluating Prokaryotic Species. Nature Reviews Microbiology. 2005; 3(9):733.

9. Godfray HC. Challenges for Taxonomy. Nature. 2002; 417(6884): 17.

10. Quast C, Pruesse E, Yilmaz P, Gerken J, Schweer T, Yarza P, et al. The SILVA Ribosomal RNA Gene Database Project: Improved Data Processing and Web-Based Tools. Nucleic Acids Research. 2012; 41(D1):D590-6.

11. Yarza P, Yilmaz P, Pruesse E, Glöckner FO, Ludwig W, Schleifer KH, et al. Uniting the Classification of Cultured and Uncultured Bacteria and Archaea Using t rRNA Gene Sequences. Nature Reviews Microbiology. 2014; 12(9):635.

12. Beye M, Fahsi N, Raoult D, Fournier PE. Careful Use of $16 \mathrm{~S}$ rRNA Gene Sequence Similarity Values for the Identification of Mycobacterium Species. New Microbes and New Infections. 2018; 22:24-9.

$$
\begin{aligned}
& \text { يروهش حاضر انجام شده است، دنبال نشده و نتايج عددى زيادى } \\
& \text { ارائه نشده است. }
\end{aligned}
$$

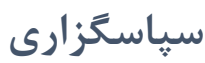

$$
\begin{aligned}
& \text { نويسندكان از تمامى كسانى كه آنها را در انجام اين يزوهش يارى } \\
& \text { كردند، تشكر و قدردانى مى كنند. }
\end{aligned}
$$

13. Edgar RC. MUSCLE: A Multiple Sequence Alignment Method With Reduced Time and Space Complexity. BMC Bioinformatics. 2004; 5(1):113.

14. Tamura K, Peterson D, Peterson N, Stecher G, Nei M, Kumar S. MEGA5: Molecular Evolutionary Genetics Analysis Using Maximum Likelihood, Evolutionary Distance, and Maximum Parsimony Methods. Molecular Biology and Evolution. 2011; 28(10):2731-2739.

15. Eisen JA. The RecA Protein as a Model Molecule for Molecular Systematic Studies of Bacteria: Comparison of Trees of RecAs and 16S rRNAs from the Same Species. Journal of Molecular Evolution. 1995; 41(6):1105-1123.

16. Hofmann K, Bucher P, Falquet L, Bairoch A. The PROSITE Database, Its Status in 1999. Nucleic Acids Research. 1999; 27(1):215-219.

17. Li W, Godzik A. Cd-hit: A Fast Program for Clustering and Comparing Large Sets of Protein or Nucleotide Sequences. Bioinformatics. 2006; 22(13):1658-1659.

18. Fu L, Niu B, Zhu Z, Wu S, Li W. CD-HIT: Accelerated for Clustering the Next-Generation Sequencing Data. Bioinformatics. 2012; 28(23):3150-3152.

19. Federhen S. The NCBI Taxonomy Database. Nucleic Acids Research. 2011; 40(D1):D136-143.

20. Coenye T, Vandamme P. Use of the Genomic Signature in Bacterial Classification and Identification. Systematic and Applied Microbiology. 2004; 27(2):175-185.

21. Stackebrandt E, Goebel BM. Taxonomic Note: A Place for DNA-DNA Reassociation and 16S rRNA Sequence Analysis in the Present Species Definition in Bacteriology. International Journal of Systematic and Evolutionary Microbiology. 1994; 44(4):846-849.

22. Woo PC, Tsoi HW, Leung KW, Lum PN, Leung AS, Ma CH. Identification of Mycobacterium NeoaurumIsolated From a Neutropenic Patient With Catheter-Related Bacteremia by 16S rRNA Sequencing. Journal of Clinical Microbiology. 2000; 38(9):3515-3517.

23. Berson AE, Peters MR, Waleh NS. Nucleotide Sequence of RecA Gene of Aquaspirillum Magnetotacticum. Nucleic Acids Research. 1990; 18(3):675.

24. Chintapalli SV, Bhardwaj G, Babu J, Hadjiyianni L, Hong Y, Todd GK, et al. Reevaluation of the Evolutionary Events Within RecA/RAD51 Phylogeny. BMC Genomics. 2013; 14(1):240. 